\title{
Growth rates of main and reciprocal crosses of Isa Brown and local chickens
}

\author{
$*^{1}$ Nwaogwugwu, U. C. and ${ }^{2}$ Udoh, U. H.
}

${ }^{\prime}$ Department of Animal Science and Fisheries, Abia State University, Uturu, P.M.B. 7010, Umuahia Nigeria.

${ }^{2}$ Department of Animal Science, University of Uyo, P.M.B 1017, Uyo, Nigeria

*Corresponding Author: ugwumbaisaac@gmail.com, +2348064368510

\begin{abstract}
The absolute and relative instantaneous growth rates of $F_{1}$ hybrid chickens were determined at 2-10 and 12-20 week periods of growth. The hybrids were hatched from eggs laid by 69 Isa Brown and local chicken parents. A total of 123, 49 and 116 chicks of Isa Brown x frizzle feathered (IBxF), Isa Brown x naked neck (IBxNa) and Isa Brown x normal feathered IBxN) main crosses and 137, 42 and 64 chicks of frizzle feathered $x$ Isa Brown (FxIB), naked neckx Isa Brown (NaxIB) and normal featheredx Is a Brown (NxIB) reciprocal crosses, respectively were produced at day-old. The greatest absolute growth rates of $49.44 \mathrm{~g} /$ week at 2-10 weeks and $71.11 \mathrm{~g} /$ week at 12-20 weeks were obtained from IBxN and FxIB genotypes, respectively. Instantaneously, IBxNa had the greatest rate of $0.28 \mathrm{~g} /$ time at 2-10 weeks, while IBxF and NaxIB each at 12-20 weeks were found to grow at the greatest rate of $0.091 \mathrm{~g} / \mathrm{time}$, respectively. It was concluded that normal and naked neck genes could be utilised in main crosses to develop fast growing broiler chicks while frizzle and naked neck genes could be used in reciprocal crosses to improve good laying pullets without precocious maturity.
\end{abstract}

Keywords: Growth rate, main and reciprocal crosses, Isa Brown, local chickens.

\section{Introduction}

Growth is an important characteristic of animals. It gives the idea of how the body size of animals changes with age. Body size is therefore a function of time. Brody (1949) had developed models for studying biological growth in many fields including animal science. These models specify the rates at which animals grow both at a given period of time and at any instance in their life time. This gives rise to the concepts of absolute growth and instantaneous relative growth rates. Whereas absolute growth considers change in body size in relation to a period of time, instantaneous relative growth rate is the change in body size at time t. Absolute growth rate has been estimated from regression analysis of body weight on age (Ibe, 1993). The growth rate of animals may be considered an important information in constructing selection index for multiple traits selection for different production purposes. Genetic and nongenetic factors affect the growth rate. As a non-genetic factor, Sonaiya et al. (1986) reported that age is a major determinant of growth and physiological development in animals. Fayeye et al. (2005) reported that the greatest growth rate in the life time of an animal is attained at its point of inflection which corresponds to its age at sexual maturity (Gille, 2004). It therefore follows that animals with greater growth rate tend to reach sexual maturity earlier and may have higher average daily gain since the relative accuracy of regression of weight on time as an estimator of absolute growth rate has been found to compare with average daily gain (Liu et al., 1991). The objective of this work was to determine the absolute and instantaneous growth rates of the crossbred chickens as selection criteria for either broilers or laying chickens. 


\section{Growth rates of crossbred chickens}

\section{Material and methods Experimental site}

The research was conducted at the poultry unit of Teaching and Research Farm, Michael Okpara University of Agriculture, Umudike, Nigeria. The University is located on Latitude $05^{\circ} 29^{\prime}$ North of Equator and Longitude $07^{\circ} 33^{\prime}$ East of Greenwich Meridian. It is approximately $122 \mathrm{~m}$ above sea level within the rainforest zone of South-East Nigeria. Maximum ambient temperature of the area ranges from $27^{\circ} \mathrm{C}$ to $36^{\circ} \mathrm{C}$ during the hot period of the year (November - April) and minimum ambient temperature ranges from $20^{\circ} \mathrm{C}$ to $26^{\circ} \mathrm{C}$ during the cold rainy season (May September). Relative humidity ranges from $57 \%-91 \%$. The climate is described as hot humid tropics (Nwaogwugwu et al., 2009).

\section{Composition of experimental chickens and their management}

A total of 69 parents of exotic (Isa Brown) and three genotypes of local (frizzle feathered, naked neck and normal feathered) chickens procured from commercial farms and local markets, respectively were used in the experiment. The exotic chickens consisted of 9 Isa Brown cocks and 27 Isa Brown hens, while the local chickens consisted of 3 frizzle feathered, 3 naked neck and 3 normal feathered cocks; 8 frizzle feathered, 7 naked neck and 9 normal feathered hens. The birds were kept on deep litter pens measuring $2.65 \times 1.67 \mathrm{~m}^{2}$. They were mated in main (using Isa Brown cocks on local hens) and reciprocal (using local cocks on Isa Brown hens) order by natural means. The birds were fed a layer mash containing 2650 metabolisable energy per kilogram weight (ME $/ \mathrm{kg}$ ) and $16.5 \%$ crude protein (CP) ad libitum. Vitamin supplement was administered to the birds through drinking water.
Fertile eggs were collected according to their pedigree, stored in containers in cool, dry place, set and hatched in locally constructed incubator at weekly intervals. The chicks were identified according to their pedigree. A total of 531 first filial generation $\left(F_{1}\right)$ unsexed chickens belonging to 6 genotypes of main (Isa Brown x frizzle feathered, IBxF; Isa Brown $\mathrm{x}$ naked neck, IBxNa; Isa Brown x normal feathered, IBxN) and reciprocal (frizzle feathered x Isa Brown, FxIB; naked neck x Isa Brown, NaxIB; normal feathered $\mathrm{x}$ Isa Brown, NxIB) crosses were produced in 12 consecutive hatches at day-old. The number of $\mathrm{F}_{1}$ birds for IBxF, IBxNa, IBxN, FxIB, NaxIB and NxIB genotypes was 123, $49,116,137,42$ and 64 , respectively. They were brooded together in cages of $79 \times 67 \times$ $61 \mathrm{~cm}^{3}$ dimension each, constructed on deep litter pens of $2.65 \times 1.67 \mathrm{~m}^{2}$ dimension each. Brooding lasted for 4 weeks per hatch. The birds were fed and provided cool, clean water ad libitum. Feeding was done in starter and grower phases. In starter phase (day1 to 6

weeks), the birds were fed starter mash containing $2800 \mathrm{kcal} \mathrm{ME} / \mathrm{kg}$ and $20 \%$ crude protein $(\mathrm{CP})$ and during the grower phase (6-20 week), they were fed grower mash containing $2550 \mathrm{kcal} \mathrm{ME} / \mathrm{kg}$ and $15 \%$ $\mathrm{CP}$. The chicks were vaccinated at day-old against Newcastle disease intraoccularlly and administered Anti-para broad spectrum antibiotics, erythromycin and E.S.T -MIX WSP (Erythromycin, sulfadiazine, Trimethoprim) against bacterial diseases.

Data collection and measurement of body weight

Data on body weight were collected on individual chickens at biweekly intervals from 2 to 20 weeks on both sexes. Body weight (BW) was measured in grams $(\mathrm{g})$, using Ohaus electronic sensitive weighing scale (Model CS 5,000) with sensitivity of $2.00 \mathrm{~g}$. 


\section{Nwaogwugwu and Udoh}

\section{Statistical analyses}

Absolute growth rate was determined from simple linear regression of body weight on age of the crossbred chickens. The simple regression model fitted to body weight data was of the form:

$\mathrm{Bw}_{\mathrm{i}}=\mathrm{a}+\mathrm{b}(\text { Age })_{\mathrm{i}}+E_{i}$

$\mathrm{Bw}_{\mathrm{i}}$ is $\mathrm{i}^{\text {th }}$ body weight; a, regression constant (intercept); b, required growth rate and $E_{i}$ random error.

Relative instantaneous growth rate was determined by Brody's (1949) twoparameter function as expressed below.

\section{$\mathrm{BW}_{\mathrm{t}}=\mathrm{Ae}^{\mathrm{kt}}$}

$\mathrm{BW}_{\mathrm{t}}$ is body weight at time $\mathrm{t}$; $\mathrm{A}$, constant; $\mathrm{k}$, required instantaneous growth rate and $t$, time of measurement in weeks. A and $\mathrm{k}$ were estimated following logarithmic transformation provided in below.

$\mathrm{LnBW}_{\mathrm{t}}=\mathrm{LnA}+\mathrm{kt}$

$\mathrm{Ln}$ is the Naperian logarithm. The coefficient, $\mathrm{k}$ was a measure of the increase in body weight at any time $t$. All regression analyses were carried out with (IBM SPSS Statistics, 2011) computer programme.

The absolute and relative instantaneous growth rates of $F_{1}$ hybrid chickens were determined at 2-10 and 12-20 week periods of growth. The hybrids were hatched from eggs laid by 69 Isa Brown and local chicken parents. A total of 123, 49 and 116 chicks of Isa Brown $x$ frizzle feathered (IBxF), Isa Brown $\mathrm{x}$ naked neck (IBxNa) and Isa Brown $x$ normal feathered IBxN) main crosses and 137, 42 and 64 chicks of frizzle feathered x Isa Brown (FxIB), naked neck x Isa Brown (NaxIB) and normal feathered $\mathrm{x}$ Isa Brown (NxIB) reciprocal crosses, respectively were produced at day-old. The greatest absolute growth rates of $49.44 \mathrm{~g} /$ week at 2-10 weeks and 71.11 $\mathrm{g} /$ week at 12-20 weeks were obtained from IBxN and FxIB genotypes, respectively. Instantaneously, IBxNa had the greatest rate of $0.28 \mathrm{~g} /$ time at $2-10$ weeks, while IBxF and NaxIB each at 12-20 weeks were found to grow at the greatest rate of 0.091 $\mathrm{g} /$ time, respectively. It was concluded that normal and naked neck genes could be utilised in main crosses to develop fast growing broiler chicks while frizzle and naked neck genes could be used in reciprocal crosses to improve good laying pullets without precocious maturity.

Table 1: Absolute growth rates of main and reciprocal crossbred chickens (2-10 weeks)

\begin{tabular}{llccc}
\hline Genotype & Regression Equation & $\mathbf{R}^{2}$ & SE & Significance \\
\hline Main cross & & & & $* * *$ \\
IBxF & $\mathrm{BW}_{\mathrm{i}}=-53.89+44.79 \mathrm{~A}$ & 88.50 & 45.67 & $* * *$ \\
$\mathrm{IBxNa}$ & $\mathrm{BW}_{\mathrm{t}}=-72.97+49.42 \mathrm{~A}$ & 92.00 & 41.28 & $* * *$ \\
$\mathrm{IBxN}$ & $\mathrm{BW}_{\mathrm{t}}=-58.29+49.44 \mathrm{~A}$ & 87.60 & 52.63 & \\
Reciprocal cross & & & & $* * *$ \\
FxIB & $\mathrm{BW}_{\mathrm{t}}=-58.81+49.21 \mathrm{~A}$ & 86.80 & 54.36 & $* * *$ \\
NaxIB & $\mathrm{BW}_{\mathrm{t}}=-36.36+40.73 \mathrm{~A}$ & 81.10 & 55.67 & $* * *$ \\
NxIB & $\mathrm{BW}_{\mathrm{t}}=-49.75+45.84 \mathrm{~A}$ & 78.00 & 68.86 & \\
\hline
\end{tabular}

$\mathrm{SE}=$ Standard error of estimate*** $=$ Very highly significant $(\mathrm{P}<0.001), \mathrm{A}=$ Age

$\mathrm{IBF}=$ Isa Brown $\times$ Frizzle feathered main cross, $\mathrm{IBNa}=$ Isa Brown $\times$ Naked neck main

cross, $\mathrm{IBN}=$ Isa Brown $\mathrm{x}$ Normal feathered main cross, FIB= Frizzle feathered $\mathrm{x}$ Isa

Brown reciprocal cross, $\mathrm{NaIB}=$ Naked neck $\mathrm{x}$ Isa Brown reciprocal cross, $\mathrm{NIB}=$ Normal

feathered $\mathrm{x}$ Isa Brown reciprocal cross.

The instantaneous relative growth rates of main and reciprocal crossbred chickens at 2-10 weeks of age are shown in Table 2.
These rates were $0.26,0.280 .25,0.25,0.23$ and 0.24 for IBxF, IBxNa, IBxN, FxIB, NaxIB and NxIB genotypes, respectively. 


\section{Growth rates of crossbred chickens}

Table 2: Instantaneous relative growth rates of main and reciprocal crossbred chickens 2- 10 weeks)

\begin{tabular}{ll}
\hline Genotype & Instantaneous relative growth equation \\
\hline Main cross & \\
IBxF & $\mathrm{BW}_{\mathrm{t}}=0.5533_{\mathrm{e}} 0^{0.26 \mathrm{t}}$ \\
$\mathrm{IBxNa}$ & $\mathrm{BW}_{\mathrm{t}}=0.541 \mathrm{e}_{\mathrm{e}}^{0.28 \mathrm{t}}$ \\
IBxN & $\mathrm{BW}_{\mathrm{t}}=0.5694 \mathrm{e}^{0.25 \mathrm{t}}$ \\
Reciprocal cross & \\
FxIB & $\mathrm{BW}_{\mathrm{t}}=0.5670 \mathrm{e}^{0.25 \mathrm{t}}$ \\
NaxIB & $\mathrm{BW}_{\mathrm{t}}=0.569 \mathrm{e}^{0.23 t}$ \\
NxIB & $\mathrm{BW}_{\mathrm{t}}=0.5696 \mathrm{e}^{0.24 t}$ \\
\hline
\end{tabular}

$\mathrm{t}=$ Instantaneous time; $\mathrm{e}=$ base of natural (Naperien) logarithm

$\mathrm{IBF}=$ Isa Brown $\mathrm{x}$ Frizzle feathered main cross, $\mathrm{IBNa}=$ Isa Brown $\mathrm{x}$ Naked neck main

cross, IBN = Isa Brown $\mathrm{x}$ Normal feathered main cross, FIB= Frizzle feathered $\mathrm{x}$ Isa

Brown reciprocal cross, NaIB $=$ Naked neck $x$ Isa Brown reciprocal cross, $\mathrm{NIB}=$ Normal

feathered $\mathrm{x}$ Isa Brown reciprocal cross.

Absolute and Instantaneous Relative Growth Rates of the Main and Reciprocal Crossbred Chickens at 12-20 Weeks of Age

The absolute growth rates of main and reciprocal crossbred chickens at $12-20$ weeks of age are presented in Table 3. The growth rates (g/week) of the genotypes, represented by the regression coefficients, were positive and very highly significant $(\mathrm{P}<001)$. The coefficients of determination $\left(R^{2}\right)$ were all high except for that of NxIB which was 48.8. Among the genotypes, FxIB individuals had the fastest absolute growth rate $(71.11 \mathrm{~g} /$ week), followed by $\operatorname{IBxNa}(71.04 \mathrm{~g} /$ week $)$.

Table 3: Absolute growth rates of main and reciprocal crossbred chickens (12-20 weeks)

\begin{tabular}{lllll}
\hline Genotype & Regression Equation & $\mathbf{R}^{2}$ & SE & Significance \\
\hline Main cross & & & & \\
IBXF & $\mathrm{BW}_{\mathrm{i}}=-325.82+69.87 \mathrm{~A}$ & 67.80 & 136.46 & $* * *$ \\
IBXNa & $\mathrm{BW}_{\mathrm{i}}=-295.75+71.04 \mathrm{~A}$ & 78.30 & 105.81 & $* * *$ \\
IBXN & $\mathrm{BW}_{\mathrm{i}}=-261.04+68.11 \mathrm{~A}$ & 62.60 & 149.15 & $* * *$ \\
Reciprocal cross & & & & \\
FXIB & $\mathrm{BW}_{\mathrm{i}}=-315.76+71.11 \mathrm{~A}$ & 65.60 & 145.81 & $* * *$ \\
NaxIB & $\mathrm{BW}_{\mathrm{i}}=-299.10+65.57 \mathrm{~A}$ & 59.40 & 153.67 & $* * *$ \\
NXIB & $\mathrm{BW}_{\mathrm{i}}=-291.46+68.61 \mathrm{~A}$ & 48.80 & 198.92 & $* * *$ \\
\hline
\end{tabular}

$\mathrm{SE}=$ Standard error of estimate, $* * *=$ Very highly significant $(\mathrm{P}<0.001), \mathrm{A}=$ Age IBF $=$ Isa Brown $\mathrm{x}$ Frizzle feathered main cross, IBNa $=$ Isa Brown $x$ Naked neck main cross, IBN = Isa Brown $x$ Normal feathered main cross, FIB= Frizzle feathered $\mathrm{x}$ Isa Brown reciprocal cross, NaIB =

Naked neck x Isa Brown reciprocal cross, NIB= Normal feathered $\mathrm{x}$ Isa Brown reciprocal cross.

The instantaneous relative growth rates of main and reciprocal crossbred chickens at 12-20 weeks are shown in Table 4. The values of the instantaneous growth equations were less than those at 210 weeks of age. Instantaneous growth rate of the reciprocal crosses were greater than those of the main crosses, judging from the exponents of the instantaneous growth equations.

Table 4 : Instantaneous relative growth rates of main and reciprocal crossbred chickens (12-20 weeks)

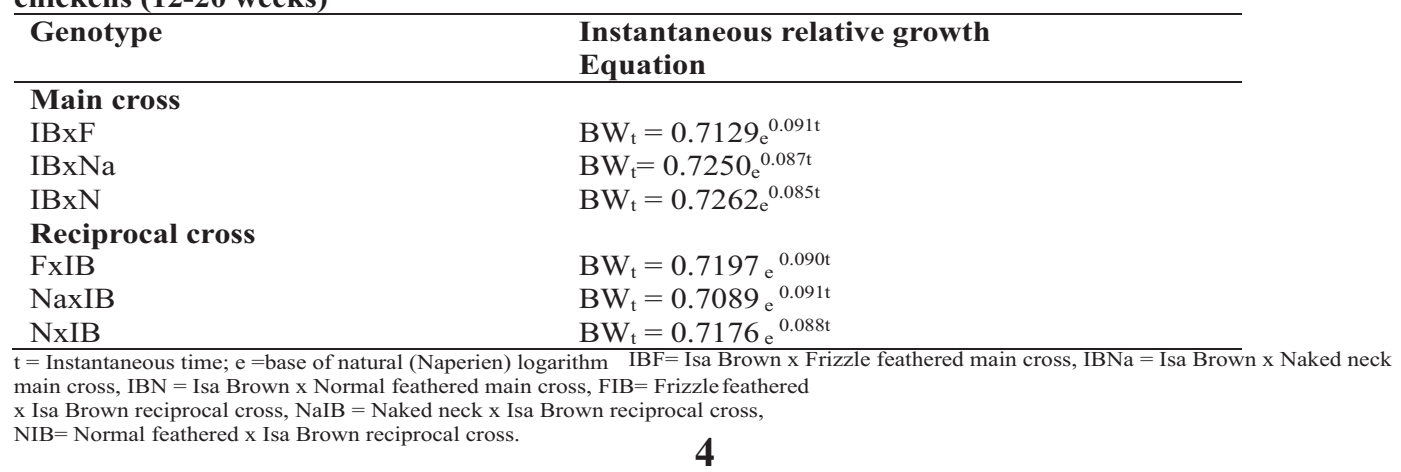




\section{Nwaogwugwu and Udoh}

\section{Discussion}

The absolute growth rates obtained in Table 1 were generally greater than $40.45,20.07$, $35.08,51.80,42.37,40.23$ and 35.55 reported by Nwaogwugwu (2008) for pure naked neck, naked neck x frizzle, naked neck x normal, pure frizzle, frizzle x naked, frizzle $\mathrm{x}$ normal and pure normal local chickens. This supports the fact that crossbreeding results in faster improvement, especially, in the first filial $\left(F_{1}\right)$ generation with respect to positive heterosis and complementary interaction effects of genes in the crossbred (Ibe, 1998). IBxN recorded the greatest growth rate followed by FxIB and IBxNa. This indicates that frizzle and naked neck genes may confer faster growth rate to chickens. This advantage has been utilized in the development of fast growing and heavy chickens in hot environment (Patra et al., 2002; Mahrous et al., 2008). The instantaneous relative growth rates of the chickens obtained in Table 2 indicated their rate of growth at any point in time. At any time, $\mathrm{t}$, between 2 and 10 weeks of age, main cross IBxNa gained more weight than the other crossbreds. This implies that their rate of converting feed to meat was higher compared to other genotypes. The absolute growth rates presented in Table 3 indicated that the chickens gained weight as they advanced in age. The high values of $\mathrm{R}^{2}$ associated with these rates are indications that the time spent in producing animals is a strong determinant of their body weight during their growing stage before they reach point of inflection. This result agreed with the findings of Sonaiya et al. (1986) that age is an important determinant of growth and physiological development in animals. The highest absolute growth rate obtained for FxIB and NaxIB collaborated with the work done by Ibe (1992) that frizzle feathered and naked neck individuals in a tropical environment matured earlier than individuals with normal feathering, suggesting that this advantage influences total egg production in a laying house. The result is also similar to the finding of Oke (2011) who reported highest growth rate of $51.80 \mathrm{~g} /$ week in homozygous frizzle $(\mathrm{F} / \mathrm{F})$ followed by $42.37 \mathrm{~g} /$ week in heterozygous frizzle and naked neck (F/Na) pullets. Ibe (1993) obtained 57.50, 45.43, 55.59, 43.46, 59.12 and $45.66 \mathrm{~g} /$ week as absolute growth rates which were not significant for male and female normal, naked- neck and frizzle feathered genotypes of Nigerian local chickens. The greatest rate of growth in the life time of an animal is attained at its point of inflection which corresponds to its age at sexual maturity (Gille, 2004). It therefore, follows that animals with greater rate of growth tend to reach sexual maturity earlier and may have higher average daily gain since the relative accuracy of regression of weight on time as an estimator of absolute growth rate has been found to compare with average daily gain (Liu et al., 1991). Attainment of early sexual maturity will also lead to increased productivity, especially in terms of number of eggs laid in a flock. The greatest absolute growth rates obtained from frizzle and naked neck individuals confirmed the fact that major genes ( $\mathrm{F}$ and $\mathrm{Na}$ ) enhanced performance (Cahaner et al., 2008) and impacted faster growth rate (Deeb and Cahaner, 1994) to their genotypes in tropical environment as a result of their productive advantage (Horst, 1988) over their normal feathered counterparts. The fastest growth rate obtained from FxIB showed that these birds have potential genotype for broiler development, thus confirming the findings of Nwachukwu et al. (2006). The least growth rate $(65.57 \mathrm{~g} /$ week $)$ obtained from NaxIB genotype indicated that though, the genotype carried naked neck gene, the mating system is very important and is 


\section{Growth rates of crossbred chickens}

capable of influencing growth in different ways. The growth rates of the main crosses were generally greater than those of the reciprocal crosses. This is an indication that exotic cocks should be used to cross local hens for improvement of growth rate and other growth related traits. The instantaneous relative growth rates of the chickens at $12-20$ weeks (Table 4 ) which were smaller compared to those at 2-10 weeks of age indicate that rate of growth at any moment in the last growing stage was slower than the younger age. This reveals that growth retards with age due to senescence. The greater instantaneous growth rate of the reciprocal crosses obtained in Table 4 suggested that although the reciprocal crossbreds did not grow faster at early stage have the potential for faster growth and

development close to point of inflection. This indicated that these birds may possess greater egg production attributes since at point of inflection pullets are known to channel nutrients for egg formation. This greater instantaneous growth rates results from the mating system which determines the functional combination of genes in an individual that contributes to its overall performance.

\section{References}

Brody, S. 1945. Bioenergetics and growth. Rheinhold Publishing Corporation, New York, USA.

Cahaner, A., Deeb, N. and Gutman, M. 2008. Effects of the naked neck (Na) gene on The performance of fast-growing broilers at normal and high ambient temperatures. Poultry Science, 87: 17-27.

Deeb, N., Cahaner, A., 1994. Genotypeby-environment interaction and heat toleration of naked-neck broilers. Proceedings of the 5th World Congress on Genetics
Applied to Livestock Production Vol 20, Guelph,ON. Canada, pp 65-68.

Fayeye, T. R., Adeshiyan, A. B., Olugbami, A. A., 2005. Egg traits, hatchability and early growth performance of the Fulani-ecotype chicken. Livestock Research for Rural Development, 17: 1-7.

Gille, U. 2004. Growth curve analysis and $\begin{array}{lllllllllll}A & 1 & 1 & 0 & m & e & t & r & y & \text {. }\end{array}$ http://www.unileipzig.de/ vetana /growthe.htm Accessed 22 July 2008.

Horst, P. 1988. Nature of fowl as reservoir for genome and major genes with direct and indirect effects on productive adaptability. Proceedings of XVIII World's Poultry Congress, 4-9 September 1998, Nagoya, Japan, pp 99- 105.

Ibe, S. N., 1992. Incorporating adaptability genes in poultry breeding programmes in Nigeria. Proceedings of XIX World's Poultry Congress, Amsterdam, $\mathrm{p}$ 64.

Ibe, S. N. 1993. Growth performance of normal, frizzle and naked-neck chickens in a tropical environment. Nigerian Journal of Animal Production, 20: 25-31.

Ibe, S. N. 1998. An introduction to genetics and animal breeding. Longman Nigeria Plc, Ikeja, Nigeria, pp121122.

IBM SPSS Statistics, 2011. International Business Machine Statistical Package for Social Sciences. IBM Corp. Released 2011. IBM SPSS Statistics for Windows, Version 20.0. Armonk, NY: IBM Corp.

Liu, M. F., Makarechian, M. and Tong, A.K.W. 1991. Relationships between measures of absolute 
growth rate and between measures of relative growth in growing meat animals. Journal of Animal Breeding and Genetics, 108: 187-191.

Mahrous, M., Galal, A., Fathi, M. M. and Zein, E. A. 2008. Impact of Naked Neck (Na) and Frizzle (F) Genes on Growth Performance and Immuno competence in Chickens. International Journal of Poultry Science, 7: 45-54.

Nwachukwu, E. N., Ibe, S. N., Ejekwu, K. and Oke, U.K. 2006. Evaluation of growth parameters of main and reciprocal crossbred normal, naked neck and frizzle chickens in a humid tropical environment. Journal of Animal and Veterinary Advances, 5: 542546.

Nwaogwugwu, U. C. 2008. Effect of plumage reducing genes on growth and early lay characteristics of crossbred local chicken. M.Sc. Thesis, Michael Okpara University of Agriculture, Umudike, Abia State, Nigeria.

Nwaogwugwu, U. C., Nwachukwu, E. N., Oke, U. K. and Oguike, M. A. 2009. Evaluation of egg quality traits of pure and crossbred local chickens in the humid tropics. Animal Production Research Advances, 5: 183-188.
Oke, U. K. 2011. Influence of some major genes on growth traits of local pullets in humid tropical environment. Agriculture and Biology Journal of North America, 4: 570-576.

Patra, B. N., Bais, R. K. S., Prasad, R. B. and Singh, B. P. 2002 . Performance of naked neck $(\mathrm{Na})$ versus normally feathered colour broilers for growth, carcass traits and blood biochemical parameters in tropical climate. Asian-Australasian. Journal of Animal Sciences, 15, 1776-1783.

Sonaiya, E. B., Williams, A. R. and Oni, S. A. 1986. A biological and economical appraisal of broiler production up to 16 weeks. Journal of Animal Production Resources, 691, 73-79.

Received: $10^{\text {th }}$ September, 2018

Accepted: $21^{s t}$ December, 2018 